\title{
DESINFECCIÓN Y ESTERILIZACIÓN DE EQUIPOS
}

Myriam Rozo Alvarado *

\section{Introducción}

En este artículo nos proponemos presentar a todos los lectores interesados en actividades de limpieza y desinfección de equipos e instrumental quirúrgico, una visión ajustada a la realidad y a la práctica hospitalaria sobre los procedimientos técnicos especializados para mantener condiciones de confiabilidad, eliminando los riesgos de infección en las intervenciones quirúrgicas.

Las esporas bacterianas son los agentes más influyentes y resistentes en la práctica de lavado, desinfección y esterilización. Es allí donde se concentra, en forma prioritaria, cualquier función destinada a garantizar la utilización de equipos e instrumental esterilizados.

Presentamos el proceso adecuado para facilitar la tarea de limpieza y desinfección, con el convencimiento de que su aplicación brindará máximas garantías en la función de asistencia quirúrgica y hospitalaria que los tiempos modernos exigen. Hay que recordar que la evolución de la especie humana marcha a la par con el desarrollo tecnológico y por esa razón los procedimientos van cambiando, hasta alcanzar resultados óptimos y generosos en beneficio de la humanidad.

Es conveniente, además, ajustar el desarrollo tecnológico a los procedimientos utilizados en cada institución asistencial. En este trabajo debe imperar el concurso de mano de obra calificada y capacitada, para obtener logros y metas propuestas. Es importante resaltar que quienes están a cargo o desarrollan procesos de desinfección, limpieza y esterilización reciban en forma periódica la capacitación suficiente para que puedan ejecutar una gestión téc-

\footnotetext{
* Instrumentadora Quirúrgica, Coordinadora Central de Esterilización, Hospital de San José, Docente Facultad de Instrumentación Quirúrgica, FUCS. Bogotá, Colombia
}

nica adecuada. Por ello, el constante conocimiento del manejo de equipos y de elementos utilizados en este campo debe ser una premisa primordial. Los métodos de limpieza, desinfección, esterilización y buen manejo de la asepsia han sido desarrollados para destruir los microorganismos y sus formas vegetativas, formando parte de una serie de procesos dirigidos a eliminar el riesgo de infección.

De otra parte, resulta imperativo tener en cuenta en este tipo de actividades para la limpieza y desinfección de equipos, los diversos procedimientos técnicos diseñados por los fabricantes, tanto de equipos de esterilización como de detergentes y productos destinados a garantizar una absoluta limpieza. Con este artículo confiamos en aportar conocimiento y práctica entre quienes manejan la responsabilidad de la limpieza, desinfección y esterilización de equipos.

\section{Limpieza}

Es la remoción mecánica de toda materia extraña en el ambiente, en superficies y objetos. Lo usual en este proceso es usar agua y detergentes. El propósito es disminuir el número de microorganismos a través del arrastre mecánico, pero no asegura la destrucción de estos. Reduce la carga microbiana y protege contra la corrosión.

Los instrumentos pueden preenjuagarse y limpiarse en forma manual o mecánica. El propósito del pre-enjuague es impedir que residuos de sangre y desechos se sequen sobre los instrumentos. Estos se deben colocar en inmersión por un periodo corto o sumergir en detergente entre 10 y 15 minutos, después de la cirugía, con el propósito de bajar la biocarga, que es el número relativo de microorganismos efectivos y sospechosos que se pueden encontrar en un artículo específico o en el medio, en un momento determinado. 
En el prelavado o limpieza, el instrumental articulado debe estar en posición abierta. Se debe desmontar lo cortopunzante como agujas y hojas de bisturí; se depositan en bandejas adecuadas que los cubran completamente. Como el agua contiene sal y otros minerales, es importante conocer y controlar el contenido de estos mismos.

No se debe mantener agua con más de $350 \mathrm{mg}$ de sal por litro. Sería grave para el instrumental. Con la utilización de filtros adecuados se puede reducir casi en la totalidad la presencia de sales. Esta agua servirá para el prelavado, el lavado y el vapor del autoclave.

Un sistema simple es el lavado del instrumental a máquina, lo cual es una práctica común en países donde la mano de obra es costosa. Es importante seguir las recomendaciones del fabricante. Los detergentes que se utilicen pueden ser básicos, neutros, ácidos y en especial enzimáticos. Las soluciones empleadas en el lavado manual no deben sobrepasar la temperatura ambiental y deben seguirse al pie de la letra las instrucciones de dosificación y el tiempo de inmersión; modificar este proceso (hacer trampa) puede causar corrosión. Si se reutilizan estos productos, las sales y minerales del lavado anterior se acumulan en el líquido y atacan el material.

Cualquier tipo de jabón enzimático debe prepararse cada seis horas, en el cambio de turno. Se lavan con cepillos suaves y a temperatura ambiente (preferiblemente en agua desmineralizada o destilada).

Las máquinas de ultrasonido son muy efectivas y rápidas, siempre que se observen y respeten las siguientes reglas:

- Instrumental en posición abierta.

- No tapar el instrumental.

- No mezclar instrumental con materiales diferentes.

- Seguir las recomendaciones de dosificación del producto.

En el lavado manual es bueno tener en cuenta:

1. El detergente dual proteolítico-enzimático disuelve la sangre, desechos y partículas de la superficie de los instrumentos, lo que incluye además las áreas inaccesibles como los lúmenes.
2. Los agentes enzimáticos se deben diluir según las instrucciones del fabricante.

3. Los detergentes con poca espuma y cerca del $\mathrm{pH}$ neutro deben ser compatibles con el suministro de agua de la institución.

4. Utilizar siempre agua destilada o desmineralizada pura y limpia.

5. Utilizar detergente desinfectante no corrosivo (el hipoclorito de sodio es corrosivo). El enjuague con un yodosforo no debe exceder una hora. Es más adecuado un producto fenólico o cuaternario de amonio con inhibidores de corrosión.

Las medidas de protección para las personas que laboran allí son obligatorias y se debe utilizar, entre otros elementos: gafas, tapabocas, gorro, delantal de caucho y guantes de caucho fuertes. Si el lavado no es manual se usarán lavadoras ultrasónicas, máquinas lavadoras de instrumental y pistolas de aire comprimido. El tiempo de inmersión para una buena limpieza es de tres a cinco minutos.

\section{Desinfección}

De acuerdo con el uso a que sean destinados, la desinfección suele ser suficiente para algunos instrumentos. Según las recomendaciones de la CDC (Center for Disease Control and Prevention) y casi todos los manuales consultados, podemos clasificar el material en tres categorías.

1. Elemento médico CRÍTICO: entra en contacto con el sistema vascular o zonas estériles del organismo, o produce solución de continuidad en la piel y/o mucosas. Requiere esterilización y procedimiento adecuado.

2. Elemento médico SEMICRÍTICO: entra en contacto con mucosas y piel no intacta (p.e. endoscopios). Debe someterse a desinfección de alto grado.

3. Elemento médico NO CRÍTICO: contacto con piel íntegra, es suficiente desinfección.

La desinfección es el proceso de destruir o evitar el crecimiento de microorganismos patógenos en objetos 
inanimados. Esto reduce el riesgo de contaminación microbiano, pero no proporciona el mismo nivel de seguridad de la esterilización.

La desinfección puede clasificarse por la efectividad del proceso, es decir, la capacidad de la sustancia para matar microorganismos.

\section{Desinfección de nivel alto}

Mata toda las bacterias, virus y hongos. El proceso puede destruir esporas si el tiempo de contacto es suficiente y se cumplen otras condiciones. Se utilizará un desinfectante de nivel alto, cuando algún aparato se va a poner en contacto con tejidos intactos del cuerpo. No es necesaria la esterilización.

\section{Desinfección de nivel medio}

Mata casi todas las bacterias, virus y hongos. El proceso no ataca esporas.

\section{Desinfección de nivel bajo}

Mata bacterias vegetativas, hongos y los virus menos resistentes.

Para obtener resultados satisfactorios en la desinfección deben cumplirse los requerimientos específicos para cada proceso. El propósito del procedimiento puede determinar el método que se empleará.

Esterilización y desinfección terminales son las que se llevan a cabo para la destrucción de patógenos al final de un procedimiento invasor. El desecho orgánico y la biocarga microbiana se reducen en forma sustancial, de tal forma que los elementos serán de manipulación segura. Puede requerirse una limpieza más profunda antes de que los artículos se preparen y empaqueten para esterilización.

Lo que no debemos hacer en el área de lavado:

- Usar sabra o esponjilla.

- Emplear cepillos de cerdas fuertes.

- Utilizar detergentes fabricados para lavar ropa, platos, etc.

- Lavar con agua caliente.

- Lubricar con aceite.
- Dejar el instrumental en hipoclorito por más de diez minutos.

No olvidar: leer siempre las instrucciones del fabricante de todos los productos que se usen en el área de lavado.

Se deben secar todos los instrumentos lavados para evitar depósitos de cristales donde se pueden adherir esporas, lo cual hace más difícil la esterilización. Si se esteriliza con óxido de etileno el agua forma etilenglicol, compuesto tóxico. En el área de empaque se revisan, clasifican, seleccionan y ordenan los elementos e instrumental de acuerdo con las características de escogencia del proceso o método de esterilización. Establecer límites sobre tamaño y densidad, según las normas para cada uno de los equipos y métodos de esterilización, con base en las siguientes pautas:

- Colocar indicadores e integradores químicos para control del paquete y la carga.

- Empacar de acuerdo con los métodos de sobre u oblongo (manera de doblar tela o papel).

- Rotular el equipo y colocar el indicador químico externo que contenga el nombre del equipo, fecha que se empaca y se esteriliza, día de vencimiento y nombre de la persona que lo empaca.

- Preparar carga homogénea y acomodar de tal forma que ofrezca resistencia mínima a la circulación del agente esterilizante e impida que el aire quede atrapado.

- Organizar la carga en forma horizontal, sin tocar las paredes de la cámara, de manera que los paquetes pesados quedan en la base y los livianos en la superficie.

- Separar un espacio de $7 \mathrm{~cm}$ entre el techo de la cámara y los paquetes.

- Registrar en el formato del lote para esterilizar.

\section{Esterilizado}

Las esporas bacterianas son los microorganismos más resistentes para soportar los agentes destructores 
externos. Para un proceso de esterilización es indispensable tener en cuenta:

- Presencia del agente esterilizante.

- Temperatura requerida.

- Reproducibilidad del proceso de esterilización.

- Registro.

- Garantía de la esterilidad.

El tiempo de esterilización se conoce como ciclo del proceso y abarca:

a) Calentamiento y penetración de la sustancia.

b) Tiempo de muerte, es decir, exposición de la sustancia.

c) Factor de seguridad para la carga.

d) Evacuación o disipación de la sustancia.

Para obtener un perfecto proceso de esterilización se deben tener en cuenta los siguientes controles:

Control de la carga: es la confiabilidad del proceso de esterilización. Se usa integrador químico y debe emplearse en cada carga.

Control del paquete: el contenido del paquete también cuenta en el proceso. Se utilizan indicadores químicos dentro de cada uno.

Control del equipo: mantener siempre el mecanismo de esterilización funcionando en forma correcta. Se utiliza paquete de BOWIE-DICK y los controles de prueba, al comienzo del día.

Control del proceso: controlar mediante la identificación visual. Se utilizan cinta e indicadores externos por fuera de cada paquete.

Control de registro: documentar el resultado del proceso de esterilización y sus controles, mediante se- llos, tarjetas y libros de registro, para todos los procesos de los paquetes.

\section{Métodos de esterilización}

- Alta temperatura: son los que desnaturalizan y coagulan las proteínas.

- Baja temperatura: eliminan nuevos organismos por alquilación o producción de radicales hidróxidos libres que atacan la membrana del nuevo organismo.

Para la esterilización en frío o baja temperatura las precauciones son las mismas que para alta temperatura. Se utiliza para aquellos elementos que puedan dañarse con calor elevado, como el peróxido de hidrógeno y el óxido de etileno. Para obtener un excelente resultado se deben tener en cuenta los mismos controles que para alta temperatura.

Los controles biológicos que se están utilizando en cada uno de los diferentes sistemas de esterilización son:

- Para el ciclo de vapor: bacilos estereato termofilus.

- Para el ciclo de óxido de etileno: bacilos subtillus.

- Para el ciclo de peróxido de hidrógeno: bacilo estereato termofilus.

\section{Lecturas recomendadas}

- Cartilla: Primer Congreso de Centrales de Esterilización. Bogotá, DC, octubre 12 a 15 de 2000.

www.webs.ono.com

- Técnicas de quirófano de Berry y Kolm Atkinson. Séptima edición. Editorial Interamericana.

Coloquios de Esterilización, actualización, Bogotá año 2000.

- Esterilización de productos sanitarios por vapor. Volumen Matachana, Casa Editorial Herat, 1999.

- Resumen de seminarios y educación continuada Jhonson y Jhonson. Asociación de profesionales de centrales de esterilización, 1999.

- Resumen de seminarios y educación continuada Jhonson y Jhonson. Asociación de profesionales de centrales de esterilización, 2001.

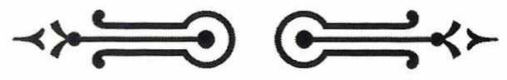

